\title{
THE EFFECT OF LIGHTING PROGRAM AND TYPE OF LITTER ON PRODUCTION AND CARCASS PERFORMANCE OF TWO BROILER GENOTYPES
}

\author{
Z. Škrbić ${ }^{1}$, Z. Pavlovski ${ }^{1}$, M. Lukić ${ }^{1}$, V. Petričević ${ }^{1}$, D. Milić ${ }^{2}$ \\ ${ }^{1}$ Institute for Animal Husbandry, Autoput 16, P.Box 23, 11080 Belgrade, Republic of Serbia \\ ${ }^{2}$ Perutnina Ptuj - Topiko a.d., Petefi Brigade 2, 24300 Bačka Topola, Republic of Serbia \\ Corresponding author: zdskrbic@gmail.com \\ Original scientific paper
}

\begin{abstract}
Light program and quality of litter are important for forming of the environment and have a direct impact on the performance and welfare of broilers. In conditions of short-photoperiod, the welfare of broilers is improved, but they lead to reduced body mass. In this sense, the aim of this study was to investigate the effects of two light programs and two types of litter on production and carcass characteristics of broilers of different genotypes. Trial was conducted on 800 day-old chicks of genotype Hubbard classic and Ross 308. For litter, two types of materials were used - chopped straw and sawdust, the same thickness. Chickens were exposed to light program with constant moderate photoperiod (LP1), and gradual extending of the photoperiod (LP2). The results suggest that the LP2 would slow down the initial growth of broilers and the occurrence of compensatory growth, without any negative effect on the final body weight and production efficiency. LP1 effect was confirmed in increasing the yield of the carcass. The effects of both light programs are not the result of their major influence, but they are consequence of the interaction with genotype. From the point established of production and carcass parameters in treatments with litter, the criteria for selection of materials for the litter should include indicators of welfare, as well as the availability and cost of certain materials.
\end{abstract}

Key words: lighting program, litter type, broiler performance

\section{Introduction}

Light program is a very important factor for the performance of a number of physiological processes and the expression of normal behaviours poultry. Lighting programs are part of the production programs in broiler fattening and it is necessary to adapt them to the characteristics of the building, nutrition program, targeted final body weights, general manufacturing management. The efficacy of the lighting program is in achieving maximum production performance of broiler 
and conservation of the welfare, which has emerged as an important goal in recent decades.

Accordingly, there is a shortening of the length of the photoperiod with the light and dark periods that can be applied continuously or discontinuously. Light programs with short photoperiod lead to reduction of the early weight gain of broilers which can solve the problems of metabolic disorders, sudden death syndrome (SDS), leg deformity (Classen et al., 1991), etc. Djukic-Stojčić and Bessei (2011) have found that the weight is the major factor affecting the activity of broilers. On the other hand, long dark periods prevent regular access to food, as a consequence, the consumption is reduced and the growth of chicken limited (Classen, 2004). Possible compromise solution is the introduction of an intermittent lighting (Ingram et al., 2000) that does not extend the duration of the photoperiod and allows frequent access to food. Given the large number of variations of light programs, there is a general interest of researchers to systematically explore this issue in order to define certain standards. In the EU countries, as well as in our country, this area is regulated with the aspect of welfare, setting the maximum duration of photoperiod during 24 hours.

Proper selection of litter in conventional broiler production is reflected, through the ambient conditions and direct contact, on the production efficiency and the welfare of broilers. The factors that determine the effectiveness of the litter are material absorption capacity, the time required for drying, fragmentation, tendency to forming of clumps, availability, price, etc. The litter should provide a sense of comfort to broilers. Wet and muddy litter loses its insulating properties and becomes a substrate for microbial growth. The material selected for the litter and quality of the litter itself may significantly affect the performance of growth and carcass quality of broilers, the occurrence and severity of foot-pad dermatitis (Bilgili et al., 1999; Cengiz et al., 2011; Škrbić et al., 2010). Types of materials used for the litter are mainly determined regionally. In order to rationalize production, alternative materials, such as sand, paper, rice hulls etc., are investigated (Grimes et al., 2002). In our country traditionally the wheat straw is used, and the use of sawdust has been significantly reduced compared to the previous decades. Straw, as litter material, is recommended by its availability and cost, while the sawdust has better absorptive capabilities.

The aim of the trial was to investigate the effects of two light programs and two types of materials used for litter on production and carcass characteristics of broiler chickens of different genotypes.

\section{Materials and Methods}

Total of 800 day-old chicks of genotype (G) Hubbard classic and Ross 308 were housed in 16 boxes, with a stocking density of $13 \mathrm{birds} / \mathrm{m}^{2}$. For litter two types (LT) of materials were used - chopped straw and sawdust. Thickness of the 
litter was $10 \mathrm{~cm}$. Lighting programs (LP) (Table 1) were applied after seven days of broiler age. The experiment was designed as a three factor experiment with 8 treatments. For all studied traits, except for food consumption and mortality, the treatment was repeated at the level of chicken. Feed consumption and mortality were recorded at the level of box and for these traits only the main effects of the factors were analysed. The standard technology of fattening broilers in floor system in duration of 42 days was applied. Chickens were fed ad libitum with 4 mixtures with protein content of $22.3 \%, 21.1 \%, 19.7 \%$ and $17.8 \%$. Water was also available ad libitum, with automatic bell drinkers. Body weight was controlled by individual weighing of chickens in the experiment, at 21 and 42 days of age. In the second part of the trial, the sample, randomly formed of 64 broilers ( 8 per treatment), was used to analyse the carcass quality based on the yield of dressed carcass and valuable carcass parts. Carcass cutting and extraction of valuable parts: breast, drumsticks, thighs and wings were made in accordance with Commission Regulation (EC) No 543/2008. After determining their masses yields were calculated (\%) in relation to pre-slaughter body weight of the animals.

Data were analyzed by a software program Statistica, vers. 6 using the method of analysis of variance and LSD test at the significance level of $0.05 \%$ and $0.01 \%$.

Table 1. Experimental light programs

\begin{tabular}{|c|c|c|c|}
\hline \multicolumn{2}{|c|}{ LP1 } & \multicolumn{2}{|c|}{ LP2** } \\
\hline Age (days) & $\begin{array}{c}\text { Photopheriod } \\
\text { (L-Light, D-Dark) }\end{array}$ & Age (days) & $\begin{array}{c}\text { Photopheriod } \\
\text { (L-Light, D-Dark) }\end{array}$ \\
\hline $0-7$ & $23 \mathrm{~L}: 1 \mathrm{D}$ & $0-7$ & $23 \mathrm{~L}: 1 \mathrm{D}$ \\
\hline $8-39$ & $16 \mathrm{~L}: 4 \mathrm{D}: 2 \mathrm{~L}: 2 \mathrm{D}$ & $8-14$ & $16 \mathrm{~L}: 8 \mathrm{D}$ \\
\hline $40-42$ & $23 \mathrm{~L}: 1 \mathrm{D}$ & $15-21$ & $16 \mathrm{~L}: 3 \mathrm{D}: 2 \mathrm{~L}: 3 \mathrm{D}$ \\
\hline & & $22-28$ & $16 \mathrm{~L}: 2 \mathrm{D}: 4 \mathrm{~L}: 2 \mathrm{D}$ \\
\hline & & $29-35$ & $16 \mathrm{~L}: 1 \mathrm{D}: 6 \mathrm{~L}: 1 \mathrm{D}$ \\
\hline & & $35-42$ & $23 \mathrm{~L}: 1 \mathrm{D}$ \\
\hline
\end{tabular}

* according to recommendation of Council Directive 2007/43/EC and Rulebook on animal welfare conditions (2010)

** Renden et al., 1996

\section{Results and Discussion}

Research results (Table 2) indicate a significant difference between the body weight of chickens aged 21 days in treatments with different lighting programs. LP2 ("step-up" program) influenced significantly slowing of the growth rate of broilers in the initial weeks of the experiment, with the established significant interaction of genotype and light program. At the end of the trial there were no significant differences in body mass due to compensatory growth. Type of material used for litter did not have any significant effect on body weight of chickens in the control measurements. 
Table 2. Body weight of chickens at the age of 21 and 42 days

\begin{tabular}{|c|c|c|c|}
\hline \multicolumn{2}{|c|}{ Treatment } & $\begin{array}{c}\text { Body mass, } g \\
21 \text { st day }\end{array}$ & $\begin{array}{l}\text { Body mass, } g \\
42 \text { nd day }\end{array}$ \\
\hline \multirow{2}{*}{ Hubbard } & Sawdust & $698,2 \pm 124,1^{\mathrm{a}}$ & $2164,3 \pm 367,1^{\mathrm{aA}}$ \\
\hline & Straw & $690,2 \pm 120,9^{\mathrm{ab}}$ & $2164,9 \pm 350,7^{\mathrm{a} A}$ \\
\hline \multirow{2}{*}{ Ross } & Sawdust & $651,7 \pm 119,9^{\mathrm{c}}$ & $2093,9 \pm 344,0^{\mathrm{b} A B}$ \\
\hline & Straw & $671,5 \pm 105,6^{b c}$ & $2033,0 \pm 321,0^{\mathrm{bB}}$ \\
\hline \multirow{2}{*}{ Hubbard } & LP1 & $711,2 \pm 110,8^{\mathrm{A}}$ & $2150,2 \pm 366,6^{\mathrm{a} A \mathrm{~B}}$ \\
\hline & LP2 & $676,5 \pm 131,3^{\mathrm{B}}$ & $2178,6 \pm 350,5^{\mathrm{a} A}$ \\
\hline \multirow{2}{*}{ Ross } & LP1 & $655,8 \pm 125,4^{\mathrm{B}}$ & $2066,8 \pm 352,4^{\mathrm{bB}}$ \\
\hline & LP2 & $667,4 \pm 99,7^{\mathrm{B}}$ & $2059,4 \pm 314,5^{\text {bB }}$ \\
\hline \multicolumn{4}{|l|}{ Significance } \\
\hline \multicolumn{2}{|l|}{ o } & $*$ & $*$ \\
\hline \multicolumn{2}{|c|}{ LT } & NS & NS \\
\hline \multicolumn{2}{|c|}{ LP } & $*$ & NS \\
\hline \multicolumn{2}{|c|}{ Gx LP } & * & NS \\
\hline
\end{tabular}

Values presented as $x \pm \mathrm{Sd}$

* a-b andA-B - Average values in each column without common marks are significantly different at the level of $5 \%$ and $1 \%$, respectively

Efficiency of utilization of food (table 3) was significantly influenced by genotype. Type of litter and lighting program did not have a significant main effect on feed conversion ratio and chick mortality.

Table 3. Feed conversion ratio and mortality of chickens in the experiment

\begin{tabular}{|c|c|c|c|}
\hline \multicolumn{2}{|c|}{ Treatment } & Feed conversion, $\mathrm{kg}$ & Mortality, \% \\
\hline \multirow{2}{*}{ Hubbard } & Sawdust & $1.90 \pm 0.10$ & 8.5 \\
\hline & Straw & $1.79 \pm 0.05$ & 3.5 \\
\hline \multirow{2}{*}{ Ross } & Sawdust & $1.88 \pm 0.02$ & 1.5 \\
\hline & Straw & $1.95 \pm 0.06$ & 0.5 \\
\hline \multirow[b]{2}{*}{ Hubbard } & IP1 & $189+012$ & 70 \\
\hline & $\frac{\text { LP1 }}{\text { LP2 }}$ & $\begin{array}{l}1.09 \pm 0.12 \\
1.79 \pm 0.02\end{array}$ & 5.0 \\
\hline \multirow{2}{*}{ Ross } & LP1 & $1.92 \pm 0.08$ & 1.0 \\
\hline & LP2 & $1.92 \pm 0.03$ & 1.0 \\
\hline \multicolumn{4}{|l|}{ Significance } \\
\hline \multicolumn{2}{|l|}{$\mathrm{G}$} & $*$ & $p=0.056$ \\
\hline \multicolumn{2}{|l|}{ LT } & NS & NS \\
\hline \multicolumn{2}{|l|}{ LP } & NS & NS \\
\hline
\end{tabular}

Values presented as $x \pm \mathrm{Sd}$

The main role of light programs is slowing the growth in the early stages of broiler fattening as to achieve physiological ripeness early in order to maximize 
muscle growth. Application of "step-up" lighting programs is based on restriction of food in the early stages, then after a period of gradual extension of the light period coming to a compensatory growth induced by abundant hormone activity. The aforementioned effect being that using LP2 reduced the increase in body weight at age 21 days, while the final body weight was not significantly influenced by light program. However, constant, long periods of darkness reduce food consumption. The results of the experiment indicate the possibility of some improvement in food conversion using LP2 depending on the genotype of broilers. Further studies should be directed toward interaction effect of examined factors. More frequent alternation of L: D period has improved the feed conversion in research by Classen et al. (2004), but in these treatments the higher mortality has been recorded. Different data on mortality, and in favour of the application of intermittent light, have been presented by Lien et al. (2009) and Vieira et al. (2010)

Contrary to our results, the type of material used for the litter in the study of Toghyani et al. (2010) showed a significant effect on body weight of broilers at 42 days of age, whereas differences in feed conversion ratio and mortality were not significant, according to the results presented. Inconsistency of research results may be due to the diversity of alternative materials studied that are used for litter. Bilgili et al. (1999) suggest that the difference in body weight may be due to reduced feed intake in treatments with sawdust, as a consequence of consuming parts of the litter, which is not the case if the sand is used. Based on the tested materials which are the most commonly used materials for the litter, the effect on production performance of broilers did not occur.

Table 4. The yield of dressed broiler chickens in experiment

\begin{tabular}{|c|c|c|c|c|c|}
\hline \multicolumn{2}{|c|}{ Treatment } & $\begin{array}{l}\text { Pre-slaughter body } \\
\text { mass, g }\end{array}$ & $\begin{array}{c}\text { Yield } \\
\text { "conventional } \\
\text { dressing" \% }\end{array}$ & $\begin{array}{l}\text { Yield } \\
\text { "Ready to } \\
\text { roast" \% }\end{array}$ & $\begin{array}{c}\text { Yield } \\
\text { "Ready to grill"\% }\end{array}$ \\
\hline \multirow{2}{*}{ Hubbard } & Sawdust & $2051.87 \pm 269.15^{\mathrm{ab}}$ & $82.41 \pm 1.49$ & $76.31 \pm 1.57$ & $67.18 \pm 1.73^{\mathrm{b}}$ \\
\hline & Straw & $2163.13 \pm 223.63^{\mathrm{a}}$ & $82.44 \pm 1.31$ & $76.43 \pm 1.41$ & $67.49 \pm 1.43^{\mathrm{ab}}$ \\
\hline \multirow{2}{*}{ Ross } & Sawdust & $2027.5 \pm 251.09^{\mathrm{ab}}$ & $82.85 \pm 1.15$ & $76.97 \pm 1.08$ & $68.71 \pm 1.57^{\mathrm{a}}$ \\
\hline & Straw & $1915.63 \pm 253.8^{b}$ & $83.23 \pm 1.98$ & $76.86 \pm 2.11$ & $68.39 \pm 2.17^{\mathrm{ab}}$ \\
\hline \multirow{2}{*}{ Hubbard } & LP1 & $2100.63 \pm 250.85$ & $82.23 \pm 0.93^{\mathrm{b}}$ & $76.20 \pm 1.07$ & $67.20 \pm 1.22^{b}$ \\
\hline & LP2 & $2114.38 \pm 256.96$ & $82.62 \pm 1.73^{\mathrm{ab}}$ & $76.54 \pm 1.80$ & $67.46 \pm 1.88^{\mathrm{b}}$ \\
\hline \multirow{2}{*}{ Ross } & LP1 & $1986.87 \pm 277.58$ & $83.59 \pm 1.77^{\mathrm{a}}$ & $77.47 \pm 1.86$ & $69.20 \pm 2.08^{\mathrm{a}}$ \\
\hline & LP2 & $1956.25 \pm 237.88$ & $82.49 \pm 1.24^{b}$ & $76.36 \pm 1.22$ & $67.91 \pm 1.42^{\mathrm{b}}$ \\
\hline \multicolumn{6}{|c|}{ Significance } \\
\hline \multicolumn{2}{|c|}{$\mathrm{G}$} & $*$ & NS & NS & $*$ \\
\hline \multicolumn{2}{|c|}{ LT } & NS & NS & NS & NS \\
\hline \multicolumn{2}{|c|}{ LP } & NS & NS & NS & NS \\
\hline \multicolumn{2}{|c|}{ G x LP } & $\mathrm{NS}$ & $*$ & NS & $*$ \\
\hline
\end{tabular}

Values presented as $\bar{x} \pm \mathrm{Sd}$

* a-b - Average values in each column without common marks are significantly different at the level of $5 \%$ 
Slaughter carcass quality and indicators of the yield of dressed carcass, valuable parts (total) and meat in the carcass, are shown in Tables 4-6.

The yields of dressed carcasses were not significantly different between treatments observed in terms of the main effects of the studied factors. Data in Table 4 indicate that the yield of classically dressed carcasses and carcasses "ready to grill" can be significantly enhanced through the use of LP1 in fattening of Ross broiler genotype, which can be explained by statistically confirmed interaction of genotype $\mathrm{x}$ light program. Interactive effect indicated increased the yield of dressed carcass by $1.1 \%, 1.29 \%$, respectively.

Data on the yield of the breast, drumsticks, thighs and wings (Table 5), as well as the yield of breast meat, drumstick and thigh meat (Table 6) in preslaughter body weight of chickens showed the absence of significant differences between the treatments, except in meat of drumsticks that was considerably influenced by the type of litter.

Light program, and the type and quality of litter in broiler fattening affect physical activity rhythm of feeding of chickens. It is believed that the broilers exposed to more frequent alternation of light and dark periods are more active during periods of light (Ferrante et al., 2006) and that the rhythm of feeding in moderate photoperiod changes so that the peak of the food consumption is reached at the beginning and at the end of the light period (Gordon, 1999). The most pronounced differences are between continuous or almost continuous and intermittent light programs. The applied light programs (LP1 and LP2) were not so much different, which has probably caused the absence of difference in the yield of carcass and valuable carcass parts. Comparing continuous and discontinuous light programs, Škrbić et al. (2011) have found a significantly higher share of breasts in female chicken carcasses exposed to continuous light. Similarly, Lien et al. (2007) have established a higher share of the breasts when photoperiod of 23 hours was applied compared to the restrictive photoperiod of 18 hours. However, in terms of the share of white-meat fillets the significance of established differences was eliminated.

Based on the carcass yield, yield of valuable carcass parts and share of abdominal fat, which ranged from 1.02 to $1.24 \%$, the influence of the material used for the litter was not confirmed, which is in accordance with the results of Bilgili et al. (1999), Toghyani et al. (2010).Established significant effect on the yield of thigh meat does indicate the importance of the choice of material for the litter, and its quality, in terms of moisture content, drying capability, skinning or tendency to form clumps, for physical activity of chicken and the development leg muscle tissue. 
Table 5. Yield of major carcass parts (\% of pre-slaughter body mass)

\begin{tabular}{|c|c|c|c|c|c|}
\hline \multicolumn{2}{|c|}{ Treatment } & Breast, \% BM & $\begin{array}{c}\text { Drumsticks, \% } \\
\text { BM }\end{array}$ & $\begin{array}{l}\text { Thighs, } \\
\% \text { BM }\end{array}$ & Wings, \% BM \\
\hline \multirow{2}{*}{ Hubbard } & Sawdust & $18.18 \pm 1.18^{\mathrm{B}}$ & $10.36 \pm 0.57$ & $12.30 \pm 0.78$ & $8.43 \pm 0.46^{\mathrm{a} A}$ \\
\hline & Straw & $18.06 \pm 1.25^{\mathrm{B}}$ & $10.61 \pm 0.68$ & $12.59 \pm 0.82$ & $8.32 \pm 0.31^{\mathrm{ab} \mathrm{AB}}$ \\
\hline \multirow{2}{*}{ Ross } & Sawdust & $20.77 \pm 2.01^{\mathrm{A}}$ & $10.20 \pm 0.47$ & $12.25 \pm 0.58$ & $8.03 \pm 0.30^{\mathrm{c} \mathrm{B}}$ \\
\hline & Straw & $19.73 \pm 1.58^{\mathrm{A}}$ & $10.36 \pm 0.55$ & $12.34 \pm 0.74$ & $8.11 \pm 0.37^{\text {bc AB }}$ \\
\hline \multirow{2}{*}{ Hubbard } & LP1 & $17.99 \pm 1.13^{\mathrm{B}}$ & $10.41 \pm 0.57$ & $12.63 \pm 0.71$ & $8.27 \pm 0.32^{\mathrm{AB}}$ \\
\hline & LP2 & $18.26 \pm 1.29^{\mathrm{B}}$ & $10.56 \pm 0.70$ & $12.27 \pm 0.87$ & $8.48 \pm 0.43^{\mathrm{A}}$ \\
\hline \multirow{2}{*}{ Ross } & LP1 & $20.51 \pm 2.07^{\mathrm{A}}$ & $10.41 \pm 0.53$ & $12.33 \pm 0.79$ & $8.08 \pm 0.34^{\mathrm{B}}$ \\
\hline & LP2 & $19.99 \pm 1.62^{\mathrm{A}}$ & $10.15 \pm 0.48$ & $12.26 \pm 0.51$ & $8.06 \pm 0.34^{\mathrm{B}}$ \\
\hline \multicolumn{6}{|c|}{ Significance } \\
\hline \multicolumn{2}{|c|}{$\mathrm{G}$} & $*$ & NS & $\mathrm{NS}$ & $*$ \\
\hline \multicolumn{2}{|c|}{ LT } & NS & NS & NS & NS \\
\hline \multicolumn{2}{|c|}{ LP } & $\mathrm{NS}$ & $\mathrm{NS}$ & NS & NS \\
\hline
\end{tabular}

Values presented as $x \pm \mathrm{Sd}$

* a-b and A-B - Average values in each column without common marks are significantly different at the level of $5 \%$ and $1 \%$, respectively

Table 6. Yield of meat from major carcass parts (\% of pre-slaughter body mass)

\begin{tabular}{|c|c|c|c|c|}
\hline \multicolumn{2}{|c|}{ Treatment } & $\begin{array}{c}\text { Breast meat } \\
\% \text { BM }\end{array}$ & $\begin{array}{c}\text { Drumstick meat } \\
\% \text { BM }\end{array}$ & $\begin{array}{c}\text { Thigh meat } \\
\% \text { BM }\end{array}$ \\
\hline \multirow{2}{*}{ Hubbard } & Sawdust & $13.07 \pm 1.92^{\mathrm{B}}$ & $5.96 \pm 0.57$ & $7.64 \pm 0.61$ \\
\cline { 2 - 5 } & Straw & $12.99 \pm 1.35^{\mathrm{B}}$ & $6.35 \pm 0.67$ & $8.12 \pm 1.17$ \\
\hline \multirow{2}{*}{ Ross } & Sawdust & $15.45 \pm 2.29^{\mathrm{A}}$ & $6.06 \pm 0.46$ & $7.90 \pm 0.61$ \\
\cline { 2 - 5 } & Straw & $14.95 \pm 1.33^{\mathrm{A}}$ & $6.24 \pm 0.45$ & $8.04 \pm 0.95$ \\
\hline \multicolumn{5}{|c|}{} \\
\hline \multirow{2}{*}{ Hubbard } & LP1 & $12.78 \pm 1.74^{\mathrm{B}}$ & $6.13 \pm 0.61$ & $7.98 \pm 0.82$ \\
\cline { 2 - 5 } & LP2 & $13.29 \pm 1.53^{\mathrm{B}}$ & $6.19 \pm 0.69$ & $7.78 \pm 1.08$ \\
\hline \multirow{2}{*}{ Ross } & LP1 & $15.69 \pm 2.19^{\mathrm{A}}$ & $6.27 \pm 0.46$ & $8.16 \pm 0.68$ \\
\cline { 2 - 6 } & LP2 & $14.71 \pm 1.35^{\mathrm{A}}$ & $6.03 \pm 0.43$ & $7.78 \pm 0.86$ \\
\hline Significance & $*$ & NS & NS \\
\hline \multicolumn{2}{|c|}{$\mathrm{G}$} & $*$ & NS & NS \\
\hline \multicolumn{2}{|c|}{ LT } & NS & NS & \\
\hline \multicolumn{2}{|c|}{ LP } &
\end{tabular}

Values presented as $x \pm \mathrm{Sd}$

*A-B-Average values in each column without common marks are significantly different at the level $1 \%$

\section{Conclusion}

The results of the experiment have shown the importance of proper selection of lighting program and the types of materials used for the litter on some production performance and carcass yield of broilers. 
Light program with gradual extending of the photoperiod (LP2) influenced the initial slowdown in growth of broiler chickens and the occurrence of compensatory growth, which provides a resolution of a number of metabolic and skeletal problems with the absence of a negative effect on the final body weight and efficiency of production. On other hand, the effect of light program comprising constant temperate photoperiod (LP1) is manifested in increasing of the carcass yield. The influence of both light programs is not the result of their main effects, but the result of the interaction with genotype.

From the point established of production and carcass parameters in treatments with litter, the criteria for selection of materials for the litter should include indicators of welfare, as well as the availability and cost of certain materials.

\title{
Acknowledgment
}

This research is part of the Project EVB: TR-31033 financially supported by Ministry of Education, Science and Technological Development of the Republic of Serbia.

\section{Uticaj svetlosnog programa i vrste prostirke na proizvodne i klanične performanse brojlera dva genotipa}

\author{
Z. Škrbić, Z. Pavlovski, M. Lukić, V. Petričević, D. Milić
}

\section{Rezime}

Svetlosni program i kvalitet prostirke su važni za formiranje ambijenta i imaju direktan uticaj na performanse i dobrobit brojlera. U uslovima skraćenog fotoperioda poboljšava se dobrobit brojlera ali oni vode redukovanoj telesnoj masi.U tom smislu, cilj rada je bio da se ispitaju efekti dva svetlosna programa $i$ dva tipa prostirke na proizvodne i klanične karakteristike brojlera različitog genotipa.Ogled je izveden na 800 jednodnevnih pilića genotipa Hubbard classic i Ross 308. Za prostirku su korišćene dve vrste materijala - seckana slama i piljevina, pri istoj debljini. Pilići su izloženi svetlosnom programu sa konstantno umerenim fotoperiodom (LP1), odnosno sa postepenim produžavanjem fotoperioda (LP2). Rezultati istraživanja su ukazali da je LP2 uticao na usporavanje početnog 
porasta brojlera i pojavu kompenzatornog porasta, bez negativnog efekta na završne telesne mase i efikasnost proizvodnje. Efekat LP1 je potvrđen u povećanju prinosa trupa. Efekti oba svetlosna programa nisu rezultat njihovog glavnog uticaja već su posledica interakcije sa genotipom. Sa aspekta utvrđenih proizvodnih i klaničnih parametara u tretmanima sa prostirkom, u kriterijume za izbor vrste materijala za prostirku bi trebalo uključiti indikatore dobrobiti, kao i dostupnost $\mathrm{i}$ troškove nabavke pojedinih materijala.

\section{References}

BILGILI SF., MONTENEGRO G.I., HESS J.B., ECKMAN M.K. (1999): Sand as litter for rearing broiler chickens. Journal Applied Poultry Research, 8, 345-351.

CENGIZ O., HESS B., BILGILI S.F., (2011): Effect of bedding type and transient wetness on footpad dermatitis in broiler chickens. Journal Applied Poultry Research, 20, 554-560.

CLASSEN H.L., ANNETT C.B., SCHWEAN-LARDNER K.V., GONDA R., DEROW D. (2004): The effects of lighting programmes with twelve hours of darkness per day provided in one, six or twelve hour intervals on the productivity and health of broiler chickens. British Poultry Science, 45, S31-32.

CLASSEN H.L., RIDDELL C., ROBINSON E.E. (1991): Effects of increasing photoperiod length on performance and health of broiler chickens. British Poultry Science, 32: 21-29.

Council of the European Union (2007): Council Directive 2007/43/CE

FERRANTE V., LOLLI S., MARELLI S., VEZZOLI G., SIRRI F., CAVALCHINI L.G. (2006): Effect of light programs, bird densities and litter types on broilers welfare. EPC 2006, Verona, XII European Poultry, Conference Verona, Italy. Word's Poultry Science Journal 62 (supplement):586.

GORDON S.H. (1999): Effect of photoperiod and feeding schedules on food usage during early life in male broilers. British Poultry Science, Vol. 40, 33-35.

GRIMES J.L., SMITH J., WILLIAMS C.M. (2002): Some alternative litter materials used for growing broilers and turkeys. World's Poultry Science Journal, 58, 515-526.

http://ec.europa.eu/food/animal/welfare/farm/broilers en.htm

INGRAM D.R. and HATTEN L.F.(2000): Effects of light restriction on broiler performance and specific body structure measurements. Journal Applied Poultry Research, 9, 501-504.

LIEN R.J., HESS J.B., BILGILI S.F. (2009): Effects of American and proposed European lighting programs on broiler live and processing performance. International Poultry Scientific Forum, Atlanta, Georgia, Proc.of Abstracts, 30, T92. 
LIEN R.J., HESS J.B., MCKEE S.R., BILGILI S.F., TOWNSED J.C. (2007): Effect of Light imtensity and Photoperiod on Live Performance, Heterophil-toLymphocyte ratio, and Processing Yields of Broilers. Poult.Sci. 86:1287-1293. OLANREWAJU H.A., THAXTON J.P., DOZIER W.A., PURSWELL J., ROUSH W.B., BRANTON S.L. (2006): A Review of Lighting Programs for Broiler Production. International Journal of Poultry Science, 5(4), 301-308.

RENDEN J.A., MORAN E.T., JR KINCAID S.A: (1996): Lighting programs for broilers that reduce leg problems wuthout loss of of performance or yield. Poultry Science, 75: 1345-1350.

Službeni glasnik RS 6/10: Pravilnik o uslovima za dobrobit životinja

ŠKRBIĆ Z., PAVLOVSKI Z., LUKIĆ M., MILIĆ D. (2011): The effect of rearing conditions on carcass slaughter quality of broilers from intensive production. African Journal ofBiotechnology, vol.10(10), 1945-1952.

ŠKRBIĆ Z., PAVLOVSKI Z., LUKIĆ M., PETRIČEVIĆ V.(2010): Assessment of Broiler Welfare in Different Stocking Densities. Proceedings (CD) of XIII European Poultry Conference, Tours, France, August 23-27 on line:http://epc2010.org/cd/index.html

TOGHYANI M., GHEISARI A., MODARESI M., TABEIDIAN S.A., TOGHYANI M. (2010): Effect of different litter material on performance and behavior of broiler chickens. Applied Animal Behaviour Science, 122, 48-52.

VIEIRA B.S., SOUZA L.F.A., ESPINHA L.P., MACARI M., FURLAN R.L. (2010): Early age thermal conditioning and lightening schedule management for broilers submitted to heat stress. Proceedings (CD) of XIII European Poultry Conference, Tours, France, August 23-27 on line:http://epc2010.org/cd/index.html DJUKIĆ STOJČIĆ M. and BESSEI W. (2011): The effect of weight load on the legs of broilers behavior. Biotechnology in Animal Husbandry, 27, 4, 1667-1671. 